\title{
ICT to Vocational Education National Curriculum Implementation in Indonesia: Requirements, Challenges, and Opportunities
}

\author{
Ramdhan Mala, Priyanto, Ranu Iskandar
}

\begin{abstract}
Implementations stage is becoming a crucial to develop a vocational education curriculum and consider of this stage a new curriculum is doing by public testing, socialized for a society and related parties, implemented teacher's training, and delivery a book guide. This research is literature review research. The aims of this research are describing (1) implementation needed of vocational education in Indonesia; (2) Challenges of vocational education curriculum implementation in Indonesia; and (3) Opportunities that gained by using ICT of vocational education implementation in Indonesia. The needs of vocational education curriculum implementation such as (1) there is a good communication of public testing and socialization (2) national trainer and master teacher must be competent and capable to guide (4) distributed the book to all of school, (5) teacher's training is efficient. Vocational education curriculum implementation challenges are (1) public testing is too short, (2) there is a society who do not get a new curriculum implementation (3) national trainer and master teacher have the differences in doing the interpretation the material in training teacher, (4) not all books is ready and need a long time to distribution a book for all of Indonesia (5) not all teachers can join the training. Taken the opportunity of ICT in Vocational Education National Curriculum implementation, such as (1) the result of public testing and socialization is stored in the form manuscripts, video, audio that can be downloaded by anyone (2) book distributed should not be in print but e-book or e-module are allowed (3) In preparing national training and master teacher and teacher's training is using microteaching, workshop, module, e-learning, and teleconference.

Keywords: ICT, Curriculum Implementation, Requirements, Opportunity, Vocational Education, Challenges.
\end{abstract}

\section{I.INTRODUCTION}

Vocational education in Indonesia has changed aims to become formal education to prepare graduated students who competent to their major, ready to work, entrepreneurship, or continuing to higher education. The need of curriculum is the one thing that can achieve that aims. Educational curriculum is important because of it is a central education system. The factor of changing the aims is era [1]. The old era, students who graduated is only have a skill who related to their major and get a job, but in this era, distruptif must dded with HOTS, 4Cs, employability skills, and digital literacy in

Revised Manuscript Received on February 05, 2020.

* Correspondence Author

Ramdan Mala*, Technology and Vocational Education, Yogyakarta State University, Indonesia, Email: ramdanmala.2018@student.uny.ac.id

Priyanto,Informatics Engineering Education, Yogyakarta State University, Indonesia, Email: priyanto@uny.ac.id

Ranu Iskandar, Technology and Vocational Education, Yogyakarta State University, Indonesia, Email: ranuiskandar.2018@student.uny.ac.id

(C) The Authors. Published by Blue Eyes Intelligence Engineering and Sciences Publication (BEIESP). This is an open access article under the CC BY-NC-ND license (http://creativecommons.org/licenses/by-nc-nd/4.0/) facing 21st centuries and IR 4.0. The changes of industrial need or society who need graduation in multi skills in era distruptif are demanding the changes of vocational education.

Vocational education curriculum in Indonesia is always changing. At least 11 changing form of vocational educational curriculum [2]. Vocational education curriculum recently is curriculum 2013 for SMK/MAK. This curriculum is aiming to produce a human resources who productive, creative, innovative, and affective through strengthening competence in domain attitude, science, and skills [3].

Although, there is developing of the curriculum, the fact shows in curriculum implementation stages still have a problem. The problem of public testing and socialization curriculum 2013 is because the government using a channel media television TVRI that have a lower rating [4]. The impact of this reason is the parents of the students and teacher do not agree with the curriculum changes. The problem of vocational curriculum implementation is distributed book for each book, it has not spread equally, and the quality of the book is not maximal[5]. It showed from Direktorat Pembinaan SMK, http://psmk.kemdikbud.go.id/kdp website for craft lesson and entrepreneur product (PKK) only available 1 book. On the other side, craft lesson and entrepreneur product (PKK) has different skills. Vocational education curriculum implementation problem in training stages such as: (1) there is a teacher who not join the training, (2) each teacher who trained complain because of the instructor has different interpretation material; (3) teacher is present the training not in full meeting; (4) there is a limitation time; (5) not all material were taught. The material is only making a RPP not in-depth assessment[6], [5].

ICT (Information and Communication Technology) is getting the answer to give the developing curriculum innovation of vocational education [7], [8]. It because ICT is e-learning that can be used for learning without limitation time, demography, fast, and anytime [9], [10]. Moreover, ICT not only for doing interaction between machine - human interaction but also human - human interaction, and then there is a collaboration between user [11]. This is exactly in curriculum implementation using ICT. However what is like the ICT that suitable for curriculum implementation.

From some the background of problem above, then the aim for this article is describing (1) vocational education curriculum implementation in Indonesia:

(2) vocational educational curriculum implementation challenges and

(3) of the opportunity that obtained using ICT in vocational education curriculum implementation in Indonesia. 
This research is giving the alternative solution to evaluation research in curriculum implementation in 2013 especially in SMK. Novelty this research in ICT is to implement the curriculum 2013 because until today there is no the research about ICT in vocational education curriculum implementation. Most of them is only about the problem without trying to give the alternative solution.

\section{II.METHODS}

This research methodology was using a literature review. The type of review used mapping review [12]. The technology used EDraw Max 5.1. The purpose of this mapping review are mapping and categorizing the literature review in the specific topic. The data collected through the search of electronic database to identify related research.

The keywords is used to search was Implementing Vocational Curriculum, disseminating Curriculum Vocational (kurikulum pendidikan kejuruan, TVET, Vocational High School (SMK)), socialization Curriculum, Training teachers for Curriculum, distributing book, combination with the literature review, problems, difficulties, needs, challenge, opportunity. The documents have been collected in form of a journal paper, prosiding paper, thesis, organization report, and web page. The quest for the relevant performed on Google Scholar, ERIC, Science direct, Portal Garuda, and engine search Google directly. Documents needed were a document that used English and Indonesia Language. The result searching of the documents were 24 manuscripts in this study. Table 1 showed the type of publications review in dataset. Table 2 showed the overview of the year publication in dataset. Table 3 showed the overview of the studies.

Table 1. Overview of type publications

\begin{tabular}{|l|c|}
\hline \multicolumn{1}{|c|}{ Type of Publication } & N \\
\hline Paper Journal & $\mathbf{1 0}$ \\
\hline Paper Proceeding & $\mathbf{1}$ \\
\hline Report of Organization & $\mathbf{5}$ \\
\hline Book & $\mathbf{2}$ \\
\hline Web page & $\mathbf{6}$ \\
\hline
\end{tabular}

Table 2. Overview of year publications

\begin{tabular}{|l|l|}
\hline Type of Publication & N \\
\hline $2016-2019$ & $\mathbf{7}$ \\
\hline $2012-2015$ & $\mathbf{6}$ \\
\hline $2008-2011$ & $\mathbf{8}$ \\
\hline $2004-2007$ & $\mathbf{0}$ \\
\hline$<2003$ & $\mathbf{4}$ \\
\hline
\end{tabular}

Table 3. Overview of the studies

\begin{tabular}{|c|c|c|c|c|}
\hline Author & Sample & Country & Data & Method \\
\hline $\begin{array}{l}\text { Retnawati et } \\
\text { al (2016) }\end{array}$ & $\begin{array}{c}22 \text { teachers } \\
\text { and vice } \\
\text { principals } \\
\end{array}$ & $\begin{array}{c}\text { Indonesi } \\
\mathrm{a}\end{array}$ & $\begin{array}{c}\text { Interviews } \\
\text { FGD }\end{array}$ & Qualitative \\
\hline $\begin{array}{l}\text { Kartowagiran } \\
\text { et al (2017) }\end{array}$ & $\begin{array}{c}\text { principals, } \\
\text { teachers, and } \\
\text { student in } 208 \\
\text { schools }\end{array}$ & $\begin{array}{c}\text { Indonesi } \\
\mathrm{a}\end{array}$ & $\begin{array}{l}\text { Quisionnairers } \\
\text { Interviews }\end{array}$ & $\begin{array}{l}\text { Mixed } \\
\text { Methods }\end{array}$ \\
\hline $\begin{array}{c}\text { Permatasari } \\
\text { andHardiyan } \\
(2018)\end{array}$ & $\begin{array}{c}\text { staff of BCA } \\
\text { bank } \\
\text { tangerang } \\
\end{array}$ & $\begin{array}{c}\text { Indonesi } \\
\mathrm{a}\end{array}$ & Quisionnairers & $\begin{array}{c}\text { Quantitativ } \\
\text { e }\end{array}$ \\
\hline $\begin{array}{c}\text { Perwira } \\
\text { (2015) }\end{array}$ & $\begin{array}{c}5 \text { teachers } \\
\text { andprincipals }\end{array}$ & $\begin{array}{c}\text { Indonesi } \\
\mathrm{a}\end{array}$ & $\begin{array}{c}\text { Interviews } \\
\text { Observation, } \\
\text { Document } \\
\end{array}$ & Qualitative \\
\hline Maria (2014) & $\begin{array}{l}\text { teachers and } \\
\text { students }\end{array}$ & $\begin{array}{c}\text { Indonesi } \\
\mathrm{a}\end{array}$ & $\begin{array}{c}\text { Interviews } \\
\text { Observation, } \\
\text { Document } \\
\end{array}$ & Qualitative \\
\hline Mayer (1987) & student doctoral & US & Quisionnairers & $\begin{array}{c}\text { Quantitativ } \\
\text { e }\end{array}$ \\
\hline $\begin{array}{l}\text { Wahzudik et al } \\
\text { (2018) }\end{array}$ & $\begin{array}{c}54 \text { respondens } \\
\text { (principals, vice } \\
\text { principals, and } \\
\text { teachers) }\end{array}$ & $\begin{array}{c}\text { Indonesi } \\
\mathrm{a}\end{array}$ & Quisionnairers & $\begin{array}{c}\text { Quantitativ } \\
\text { e }\end{array}$ \\
\hline $\begin{array}{c}\text { McBeath } \\
\text { (1997) }\end{array}$ & 38 manuscipts & Australia & Documents & Qualitative \\
\hline Suryani (2010) & 26 manuscipts & $\begin{array}{c}\text { Indonesi } \\
\mathrm{a} \\
\end{array}$ & Documents & Qualitative \\
\hline $\begin{array}{c}\text { Grant and } \\
\text { Booth (2009) }\end{array}$ & 17 manuscipts & $\begin{array}{c}\text { United } \\
\text { Kingdo } \\
\text { m } \\
\end{array}$ & Documents & Qualitative \\
\hline $\begin{array}{c}\text { Uhomoibhi } \\
(2006)\end{array}$ & 15 manuscripts & $\begin{array}{l}\text { Northern } \\
\text { Ireland }\end{array}$ & Documents & Qualitative \\
\hline
\end{tabular}

\section{III.RESULT AND DISCUSSION}

Curriculum 2013 is perfecting of curriculum KTSP that evidence for change in the standard of content, standard assessment, competency standard graduates, and standard process [13]. In Indonesia, curriculum planning that had already been prepared of central government must do the implementation. Implementations are some of strategies in national curriculum building in vocational education such as (1) public testing, (2) socialization, (3) a procurement book, (4) sources and instructor training. (5) Teacher's training [14], [13], [15], [16].

Some reviews of the results of the needs of literature or table, challenges and opportunity in using ICT with public testing, socialization, dissemination of book, sources of training, and instructor, and teacher's training in below:

Table 4. The needs of relations, challenges and opportunity using public testing, socialization, dissemination of book, and teacher's training in national implementation curriculum.

\begin{tabular}{|c|l|c|l|}
\hline & \multicolumn{1}{|c|}{ The needs of } & \multicolumn{1}{c|}{ Challenges } & \multicolumn{1}{c|}{ Opportunity } \\
\hline Public Testing & $\begin{array}{l}\text { ICT needs of delivery and communication, } \\
\text { respond, give the advise and suggestion } \\
\text { from stake holder (a parents or the student, } \\
\text { department education of local level, teachers } \\
\text { association, school superintendent, school } \\
\text { committee, DU/DI) }\end{array}$ & $\begin{array}{l}\text { Public testing is too short. } \\
\text { socialisation stored in video, text, } \\
\text { audio that can be downloaded by } \\
\text { anyone. }\end{array}$ \\
\hline Socialization & $\begin{array}{l}\text { Material delivery about the changes of } \\
\text { curriculum and about a new curriculum. }\end{array}$ & $\begin{array}{l}\text { Not all teachers are } \\
\text { understanding about a new } \\
\text { curriculum }\end{array}$ & $\begin{array}{l}\text { The result of public and } \\
\text { socialisation stored in video, text, } \\
\text { audio that can be downloaded by } \\
\text { anyone. }\end{array}$ \\
\hline
\end{tabular}

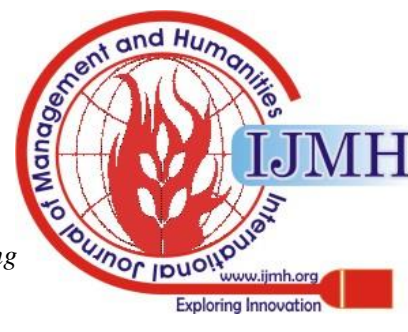




\begin{tabular}{|c|c|c|c|}
\hline Dissemination & $\begin{array}{l}\text { 1. A total SMK in Indonesia is } 13.780 \\
\text { schools. } \\
\text { 2. All of the books can be distributed to } \\
\text { the school. }\end{array}$ & $\begin{array}{l}\text { Not all the book is ready and } \\
\text { dissemination to all schools. }\end{array}$ & $\begin{array}{l}\text { Book distribution is not in printed } \\
\text { form but I e-book form. }\end{array}$ \\
\hline $\begin{array}{l}\text { Preparation of } \\
\text { national training } \\
\text { and mastering } \\
\text { teacher. }\end{array}$ & $\begin{array}{l}\text { Ability to train the teacher in standard } \\
\text { outline competence from doing analysing } \\
\text { of material, particular in designing } \\
\text { learning model, a practice of learning } \\
\text { guided evaluation. }\end{array}$ & $\begin{array}{l}\text { Each national training and } \\
\text { mastering teacher has } \\
\text { different interpretation } \\
\text { material in training the } \\
\text { teacher. }\end{array}$ & $\begin{array}{l}\text { Preparing training and mastering } \\
\text { teacher not only use a lecture } \\
\text { method but also a workshop, } \\
\text { e-learning, and teleconference. }\end{array}$ \\
\hline Teacher's training & $\begin{array}{l}\text { A teacher can be outlining a curriculum } \\
\text { contain in lesson plan and choosing a } \\
\text { learning model, and doing a scoring. }\end{array}$ & $\begin{array}{l}\text { 1. A total teacher's in } \\
\text { SMK in Indonesia is } \\
292.212 \text {. } \\
\text { 2. The selection of teacher } \\
\text { who will be trained } \\
\text { first. } \\
\text { 3. Not all teachers who } \\
\text { invited can follow } \\
\text { training until the end. }\end{array}$ & $\begin{array}{l}\text { Training not only uses a lecture } \\
\text { method but using a workshop, } \\
\text { e-learning, and teleconference. }\end{array}$ \\
\hline
\end{tabular}

\section{A. The needs of Implementation in Vocational National Curriculum}

Curriculum changing must be anticipated and understood because of a new curriculum will change the education in Indonesia. It will be good or not. This is need a contribution from stake holder until a new curriculum not be like a curriculum that not be matched.

In public testing, the government will ask advising from stake holders (parents of students, department education of local level, teachers association, school superintendent, school committee, DU/DI, higher education institution and observers education) so that a curriculum can be accepted by a society. A public testing started by a government with explaining a public testing material of curriculum 2013 such as (a) why a changing of curriculum is needed, (b) a strategy to increase educational attainment, (c) development rational curriculum, (d) framework curriculum development, (e) a changing of the standard competency, (f) curriculum SMK structure, (g) implementation strategy to stake holders[17].

Then, accepting an advising from stake holders are responding the advising and suggesting. So that a public testing needs a ICT to delivery and communicate, respond, good communication.

A curriculum that has been doing a public testing based on the number of government policy Peraturan Pemerintah No 52 dan 53 tahun 2000 and then do a curriculum socialization to a society to introduce to them about curriculum 2013. A socialization problem is a socialization media in curriculum 2013. Socialization media is using TV, a printed media, and dialogue in every province. But also it stills have a teacher who find a difficulty in implementing a curriculum 2013. On the other side, there is still have a time to do socialization in short time [18].

A need of book distribution can reach the all of SMK/MAK in Indonesia. A total SMK in 2017/2018 there is around 13.780 either public or private school in 34 provinces in Indonesia [19]. SMK in Indonesia need a book especially for national curriculum of vocational education.

A need of national training and mastering teachers must be competence in their major. Not only about mastery the material but also a national training must be guiding and giving a motivation until a teacher can be implemented a curriculum 2013. Teacher is a central in implementing a curriculum. So the teacher must be outlining contains of the give the advice and suggest from stake holder so it happens a

curriculum to lesson plan, choosing a learning model and do scoring.

\section{B. Implementation Challenging in Vocational Educational Curriculum}

Public testing is doing by (1) dialogue face to face in national level in Jakarta, Yogyakarta, Medan, Makassar and Denpasar and in this national level in 33 province; (2) dialogue virtual through site kurikulum2013.kemdikbud.go.id; and (3) written that is sent to college, community institution and observer education [17]. From the trial that have been conducted there is disappointed from Ombudsman RI who consider public testing of curriculum 2013 is too short, from 29th November - 23rd December 20[17], [20]. Socialization challenges of vocational education curriculum were not all a teachers understand about curriculum 2013 [21]. In fact, disseminating of information is still in TV, printed media, and media online. It is showed that media socialization is need more diverse again. The challenges of procurement a book have not distributed in Indonesia [22]. The fact is a book still becomes the one thing of the source that important in education, either a student's books or teacher's book. A challenges of preparation in national training and mastering teachers are the national trainer and mastering teacher has different interpretation material in teacher's training [6]. This is because instructor training is doing first and then a instructor trainer is coaching a master teacher. A national trainer and master teacher have not a master in material and capable to teach a teacher so this happen a differential interpretation.

A total teacher of SMK in Indonesia, there is around 292.212 for each people in a year 2017/2018 [19]. It is impossible if all of the teacher can join training in 1 minute and 1 time. This is making a teacher selection must be trained first. On the other side, not all teacher who invited can join the training [5].

C. An opportunity achieved by using ICT in curriculum implementation of vocational education Internet is not using in central city only.

This day internet has been reach out in all remote area in Indonesia. Indonesia is already independence of using the internet.

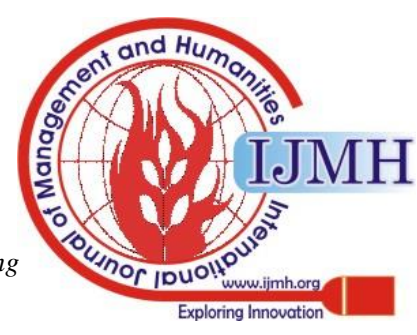


Program independent internet is supporting persistence education [23]. On the other side, teacher of SMK also have ability in using ICT. The ability in using ICT is teacher pedagogy competence. So a teacher of SMK in Indonesia must be able to use computer or smart phone and do a search using internet, and have skills in digital literacy. Teacher's skill can give an opportunity in using ICT in implementing national curriculum of vocational education. On public testing and socialization of vocational education curriculum, to face a problem is updating a result of public testing that stored in manuscript, video, audio to internet either YouTube or website Direktorat PSMK that can be downloaded by anyone. From this, the teacher can search about the result of the socialization. Book distributed should not be in printed form but also in e-module form or e-book. And then e-book must be uploaded in website Direktorat PSMK, http://psmk.kemdikbud.go.id/kategori/6/buku.An pportunity in preparing instructor and mastering teacher and training teacher is using a coach that not only used lecture method but also workshop, e-learning and teleconference [2]. The result of this research is showed the effectiveness of e-learning for training and mastering the skill [24].

\section{IV.CONCLUSION}

The curriculum implementation is the main curriculum national development of vocational education. All of the stages in curriculum national implementation have some of challenges. To complete that, knowing the needed for each stages of implementation IS to looking for an opportunity in reach out to solve the challenge. The role of ICT can help successfully the implementation of national education curriculum. It is because ICT can be connected with a person using computer. On the other side, ICT is becoming a backup storage such as Youtube, Google Drive, Whatssap, Facebook, etc.

\section{REFERENCES}

1. N. Wahzudik, H. T. Budi Santoso, and B. Sulistio, "Kendala dan rekomendasi perbaikan pengembangan kurikulum di Sekolah Menengah Kejuruan," Indones. J. Curric. Educ. Technol. Stud. IJCETS, vol. 6, no. 2, pp. 87-97, 2018.

2. S. H. Prayitno, Desain pengembangan kurikulum pendidikan vokasi perspektif internasional dan nasional. Yogyakarta: UNY Press, 2017.

3. P. Rayendra, "Wow! ANTV dan Indosiar bersaing ketat jadi TV nomor 1 (apa program rating 1?)," Tabloidbintang.com, 2015. [Online]. Available: https://www.tabloidbintang.com/film-tv-musik/ulasan/read /18429/wow-antv-dan-indosiar-bersaing-ketat-jadi-tv-nomor-1-apa-pro gram-rating-1.

4. Puskurbuk, "Pergeseran paradigma belajar abad 21," 2012. [Online]. Available: http://www.puskurbuk.org.

5. B. Kartowagiran, H. Retnawati, Sutopo, and F. Musyadad, "Evaluation of the implementation of curriculum 2013 vocational high school in Indonesia," in International Conference on Educational Research and Innovation (ICERI 2017), 2017, pp. 814-819.

6. H. Retnawati, S. Hadi, and A. C. Nugraha, "Vocational high school teachers' difficulties in implementing the assessment in curriculum 2013 in yogyakarta province of Indonesia," Int. J. Instr., vol. 9, no. 1, pp. 33-48, 2016.

7. OECD, Learning to change: ICT in schools. Paris: Organisation for Economic Co-operation and Development, 2001.

8. C. McBeath, "Curriculum dissemination: A problematic Issue in educational Change," Aust. New Zeal. J. Vocat. Educ. Reserach, vol. 5, no. 2, pp. 37-55, 1997.

9. J. O. Uhomoibhi, "Implementing e-learning in Northern Ireland: Prospects and challenges," Campus-Wide Inf. Syst., vol. 23, no. 1, pp. 4-14, 2003.

10. A. Suryani, "ICT in education: Its benefits, difficulties, and organizational development issues," J. Sos. Hum., vol. 3, no. 1, pp. 106-213, 2010.
11. S. Rodrigues, Opportunistic challenges: Teaching and learning with ICT. New York: Nova Science Publishers, Inc., 2002.

12. M. J. Grant and A. Booth, "A typology reviews: An analysis of 14 review types and associated methodologies," Heal. Info Libr J., vol. 26, no. 2, pp. 91-108, 2009.

13. Kementerian Pendidikan dan Kebudayaan, "Paparan menteri pendidikan dan kebudayaan RI: Press workshop: Implementasi kurikulum 2013." Kementerian Pendidikan dan Kebudayaan, Jakarta, p. 41, 2014.

14. Fitri, "Uji publik pengembangan kurikulum 2013," LLDIKTI Wilayah XII, 2012. [Online]. Available: http://lldikti12.ristekdikti.go.id/2012/11/30/uji-publik-pengembangan-k urikulum-2013.html.

15. V. J. Mayer and R. J. Fortner, "Relative effectiveness of four modes of dissemination of curriculum material," J. Enviromental Educ., vol. 19, no. 1, pp. 25-30, 1987.

16. J. Rudduck, Dissemination of curriculum: The humanities curriculum project, Volume 241. New York: Routledge, 2012.

17. Kementerian Pendidikan dan Kebudayaan, "Bahan uji publik kurikulum 2013." 2012.

18. Kompas.com, "Sosialisasi kurikulum 2013 mepet," 2012. [Online] Available:

https://edukasi.kompas.com/read/2012/12/20/13571460/sosialisasi.kuri kulum.2013.mepet?page=all. [Accessed: 05-Jan-2020].

19. Pusat Data dan Statistik Pendidikan dan Kebudayaan, Statistik SMK (sekolah menengah kejuruan). Jakarta: Kementerian Pendidikan dan Kebudayaan, 2017.

20. Tribunnews.com, “Ombudsman kritik uji publik revisi PP 52 dan 53 terlalu singkat," Yogyakarta, 2016.

21. J. Maria, N. K. Ananda, and Sumadi, "Kesiapan implementasi kurikulum 2013 di sekolah menengah kejuruan (SMK) (Studi kasus di SMK Muhammadiyah 2 Metro)," J. Manaj. Mutu Pendidik., vol. 2, no. 1, 2014.

22. D. E. Perwira, "Kendala-kendala implementasi kurikulum 2013 di SMKN 3 Buduran dan solusinya," J. Pendidik. Tek. Mesin, vol. 4, no. 2, pp. 21-28, 2015.

23. Kementerian Komunikasi dan Informatika, "Akses Internet Jangkau Pelosok Papua," $2018 . \quad$ [Online]. Available: https://www.kominfo.go.id/content/detail/13517/akses-internet-jangkau -pelosok-papua/0/sorotan_media. [Accessed: 06-Jan-2020].

24. I. Permatasari and Hardiyan, "Pengaruh e-learning sebagai media pelatihan dan pengembangan terhadap kinerja karyawan BCA KCU Tangerang," J. SISFOKOM, vol. 7, no. 1, pp. 1-8, 2018.

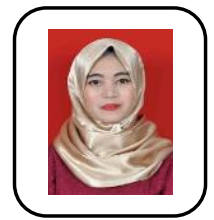

\section{AUTHORS PROFILE}

Ramdhan is a Master's student at Technology and Vocational Education, Graduate School, Universitas Negeri Yogyakarta, Indonesia. Email:ramdanmala.2018@student.uny.ac.id

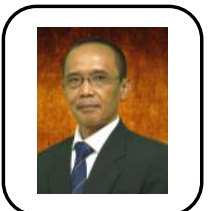

Priyanto is a Lecturer at Informatics Engineering Education, Faculty of Engineering, Universitas Negeri Yogyakarta, Indonesia. Email: priyanto@uny.ac.id. SCOPUS ID: 57201195418

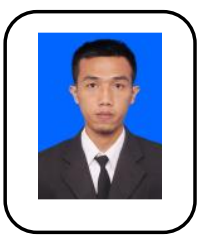

RanuIskandar is a Master's student at Technology and Vocational Education, Graduate School, Universitas Negeri Yogyakarta, Indonesia.Email: ranuiskandar.2018@student. uny.ac.id ORCID: 0000-0002-8356-9694 Google Scholar ID TWbEM5oAAAAJ

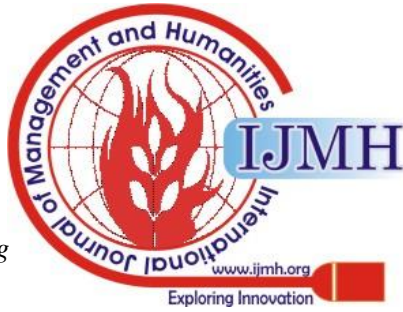

